\title{
開水路乱流構造の動的特性のビデオ画像解析 VIDEO IMAGE ANALYSIS OF OPEN CHANNEL TURBULENT FLOW
}

\author{
桑村純一 1 - 宇民正 $2 \cdot$ 上野鉄男 3 \\ Junichi KUWAMURA, Tadashi UTAMI and Tetsuo UENO \\ 1 学生会員 和歌山大学大学院 システム工学研究科（テ $640-8510$ 和歌山市栄谷 $930 ）$ \\ ${ }^{2}$ 正会員 工博 和歌山大学教授 システム工学部 (テ640-8510 和歌山市栄谷930) \\ 3 正会員 工博 京都大学 防災研究所（テ612-8235 京都市伏見区横大路下三栖）
}

\begin{abstract}
A longitudinal vertical cross-section of unsteady open channel flow was visualized by video camera. The 120 frames during 4 seconds in rising stage and the 120 frames during 4 seconds in falling stage were analyzed by cross-correlation method to obtain velocity vector distribution. The structure of large scale turbulence which drives longitudinal spiral motions were examined by using the obtained data.
\end{abstract} Key Words : video image analysis, large scale turbulence structure, vortices, upward flow,
secondary flow

\section{1.はじめに}

洪水流では、流れの境界形状は彎曲や蛇行の影響を受 け、また底面に形成される河床波の形も刻々と変化する。 さらに流れは非定常である。このため洪水流の乱流構造 は非常に複雑である。非定常の乱流構造の実験的研究は 1980年代後半に林1 らや冨永2 らにより始められ、その 後( $\mathrm{raf}^{3}$ ，4 らおよひ禰津5，6，7)８）らにより進められたが、 洪水流を模擬した非定常流を作ることが困難である、ま た流速測定とその解析が困難であるなどの問題を抱えて いる。

本研究では、実験水路における非定常流の縦断面内の 流況をビデオカメラを用いて可視化し、その画像を動的 に解析することにより、開水路における水深規模の乱流 構造である並列らせん流 ${ }^{9}$ と水路床近傍の乱流構造との 関係を明らかにしようとした。

\section{2. 実験方法及び水理条件}

幅 $40 \mathrm{~cm}$, 水路床勾配 $1 / 5000$ の長方形断面をもつ、透 明アクリル樹脂製実験水路において、流量を正弦波状に 変化させた。流量変化の周期は 120 秒, 最大流量 $1.5(1 / \mathrm{sec})$, 最低流量0.5 $(1 / \mathrm{sec})$ とした。流量と時間の関係 を図ー1に、水深と時間の関係を図ー2に示す。この流れ
に平均粒径 $0.33 \mathrm{~mm}$ のトレーサーを注入し、側壁面から $8 \mathrm{~cm}$ 離れた鉛直縦断面を水路の下方より幅 $2 \mathrm{~mm}$ のシー ト状の光で照射し、その光に反射するトレーサーを SONYデジタルビデオカメラレコーダーTRV900で水路 側方から撮影した。実験におけるレイノルズ数は 1250 〜3750、フルード数は0.04〜0.11であった。トレーサー は比重1.04のポリスチレンビーズで、これを水中処理し、 中立のものだけを抽出して使用した。
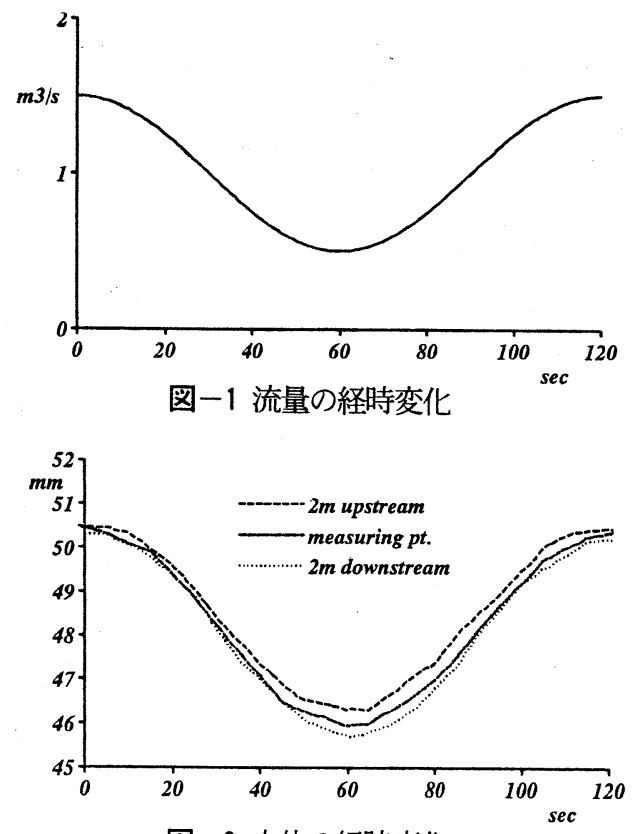

図一2 水位の経時変化 


\section{3. 解析の手法}

解析範囲は増水期のうち、測定点での水位最低時から の時間経過が 23 秒 $~ 27$ 秒の間の 4 秒間及び減水期のうち、 測定点での水位最高時からの時間経過が 32 秒〜 36 秒の 間の 4 秒間とした。撮影は $1 / 30$ 秒に1回行われているので、 4 秒間では120画像フレームに相当する。画像解析では それらの全コマを用い、相互相関法を適用して、流速べ クトル分布を得た。さらにそれらから、各種水理量（絶 対流速, 渦度, 流線) を計算し、図化した。本解析で相 互相関法を適用するにあたり、用いた画像デー夕の諸元 ならびに相関計算の諸元を表一1に示す。

表-1 画像デー夕および相関計算の諸元

\begin{tabular}{|c|c|c|c|c|}
\hline $\begin{array}{c}\text { ピクセル数 } \\
\text { (pixel) }\end{array}$ & $\begin{array}{l}\text { 相関空 } \\
\text { (pixel) }\end{array}$ & $\begin{array}{l}\text { 検索空 } \\
\text { (pixel) }\end{array}$ & $\begin{array}{c}\text { ベクトル間隔 } \\
\mathrm{dx}(\mathrm{mm}) \quad \mathrm{dy}(\mathrm{mm})\end{array}$ & ベクトル数 \\
\hline $640 \times 480$ & $\begin{array}{l}25 \times 11 \\
\sim 15 \times 5\end{array}$ & $11 \times 9$ & $3.5278 \quad 1.7639$ & $59 \times 65$ \\
\hline
\end{tabular}

\section{4. 解析結果とその考察}

\section{（1）増水期の乱流構造}

増水期にはその乱流構造が活発な時と、穏やかな時が あった。並列らせん流は摇動しているが、照射面が並列 らせん流の上昇流領域に一致した時には活発な乱流構造 が捉えられ、下降流領域に一致した時には穏やかな乱流 構造が捉えられたと考えられる。まず、活発な時の乱流 構造の例とし、て、解析開始時から $15 / 30$ 秒経過した時点 の絶対流速(流速ベクトルの大きさ)の分布を図ー3に、 また渦度分布を図一4に示す。水路床付近に大きな渦度 をもつ層が存在するが、その層の一部が上方に向けて剥 離しかかっている様子が見える。この部分は逆U字渦の 断面を示していると考えられる。これはバッファー層の 外側の大規模乱流構造で、Brown \& Thomas ${ }^{10)}$ あるいは 宇民・上野11 が指摘しているものに相当する。図一5に
鉛直方向流速分布を示す。逆U字渦の頭付近で強い上昇 流が噴出した様子を捉えることができる。図一6に流線 を示す。水路床近傍の乱流構造の概要を把握し易くする ため、本図では、河床から約1/3水深あたりの平均流速 と同じ速度で並進する移動座標系から見た流線を示した。 図ー4において強い渦度の層が剥離しかかっているとこ ろで、流線は渦を内包する興味あるパターンを示してお り、また、その渦がちょうど頭を持ち上げたところで流 れを上向きに吹き上げている様子が明膫に判読できる。

次に、穏やかな時の例として、解析開始から $77 / 30$ 秒 後の渦度分布を図一7に示す。渦の活発な動きは無く、 渦度の高い部分は水路床近傍の狭い領域だけとなり、そ れが穏やかに流下している。また、同時刻における鉛直 方向流速分布を図一8に示す。全体的に上昇流領域は少 なく下降流が卓越していることがわかる。以上のことか ら、下降流が卓越しているところでは水路床近くの乱れ は鎮静化しているようである。

図ー9には、図ー4の渦度分布で述べた逆U字渦の動き を把握するため、渦度が4.0( $1 / \mathrm{sec})$ 以上の範囲の動きを1 コマおきに同一紙面上にプロットした。同図には同時に、 それにともなって形成されたと考えられる同時点の上昇 流の領域 (鈶直方向流速成分が $2.5 \mathrm{~mm} / \mathrm{sec}$ 以上の領域)を プロットした。本図から渦度の層が時間経過と共に剥離 したりおさまったりしながら流下方向に移動していく様 子を捉えることができる。これは逆U字渦が横断方向に 摇動しているためと思われる。また、逆U字渦による噴 出流により形成された上昇流領域が平均流により運搬さ れ、変形していく様子も捉えることができるが、この領 域は上昇しないまま消减していることがわかる。すなわ ち、変形・移動時において、下端は領域が狭まると共に 河床に対して約 $6^{\circ}$ の傾斜を持って上方へ移動している のに対し、この領域の上端は水路床から見てほぼ同じ高 さを維持している。さらに本図から、逆U字渦と上昇流 領域の移動速度の差異により、時間経過と共に、上昇流 領域の位置が逆U字渦の位置より相対的に下流にずれて いっていることがわかる。

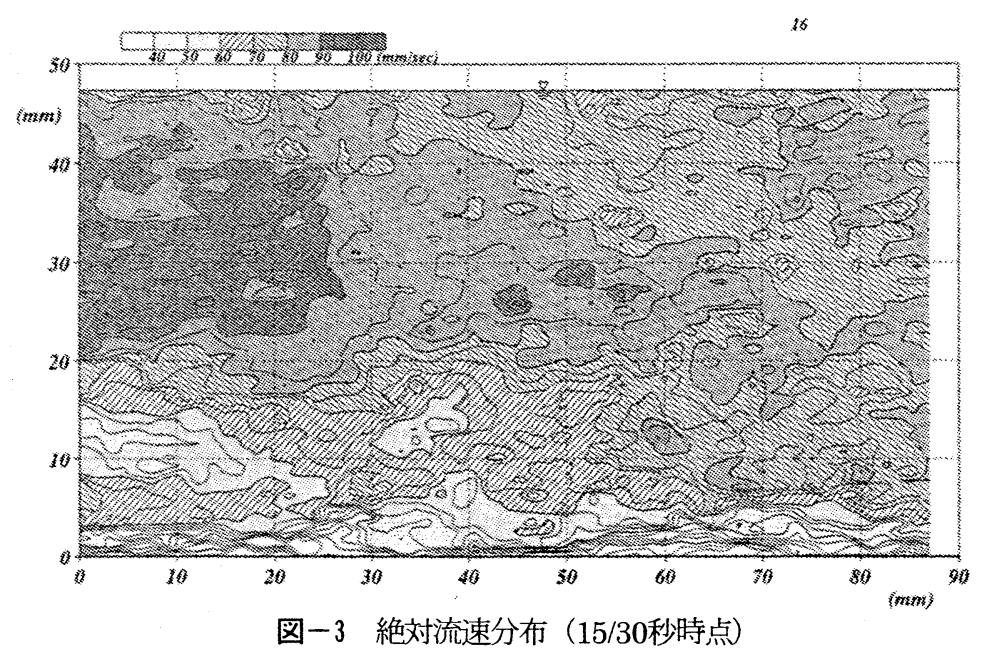



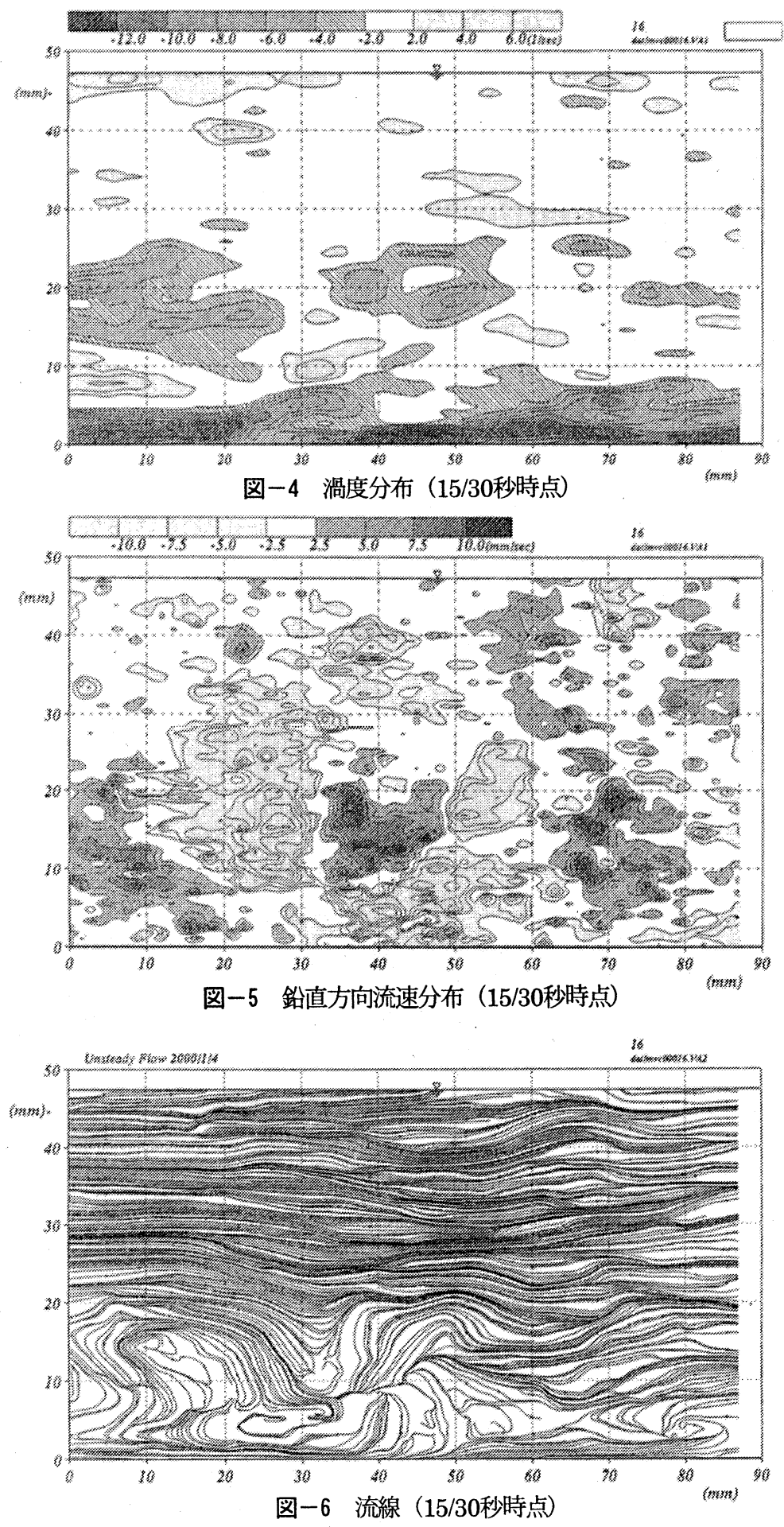

図－10には時間経過110/30secにおける鉛直方向流速 成分を示した。本図では上昇流領域は水路床近傍から ほとんど水面までを占める。このように水面まで伸び た上昇流領域はボイル構造の縦断面を意味すると考え られる。またこの図では、流下方向にいくつかの上昇 流領域が断続的に連なっていることがわかる。図一11 はそのうちの1つの領域の移動の様子を 2 コおきにプ ロットしたものと、それと同時刻に対応する渦度が

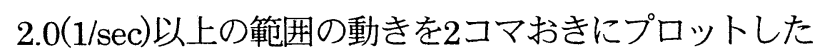
ものである。図ー9に示した場合と異なり、この場合は
上昇流領域が平均流によって運搬されながら上方へ伸 長してゆき、ついには水面に達することがわかる。こ の上昇流領域は明らかに水路床近傍から伸びているこ とや、このような強い上昇流領域は渦度分布において 水路床近傍に強い渦度領域の剥離が存在するところに 多く発生していることから、逆U字渦によるものである と考えられる。

それでは図ー9の場合には上昇流領域は上昇しないま まで消滅し、図ー11の場合には、それは水面に達しボ イルを形成するまで発達したのは何故であろうか。そ 
の理由としては 2 つが考えられる。すなわち、(1)上昇流 領域での平均的な流速は底面近くでのそれより大きい ため、ある逆U字渦の頭付近から噴出された上昇流がそ れより速く流下して行き、下流の底面近くに存在する 別の逆U字渦により噴出された上昇流と統合された結果、 水深全体にわたる上昇流が形成された。(2)一つの逆U字 渦の上に、上流側から伸びてきた別の逆U字渦が重なつ て渦の構造が2重となり、渦運動が統合された結果、水 深規模の強い上昇流が形成された。

図一11に示す上昇流と逆U字渦との関係は上記の(1) に相当すると考えられる。すなわち、ここに示されて
いる上昇流領域は、ここに示されている逆U字渦よりさ らに上流にある渦により形成され、その渦より早く流 下して図ー11に示される位置関係に達したときに上昇 流が増大されたと考えられる。一方、本実験によるか ぎり、上記(2)のメカニズムによる上昇流の発達は認め られなかった。

さらに、図ー10に示したように、強い上昇流の領域 が流下方向にいくつも連なっている所では、これらの 部分が並列らせん流の上昇流領域を形成していると考 えられる。
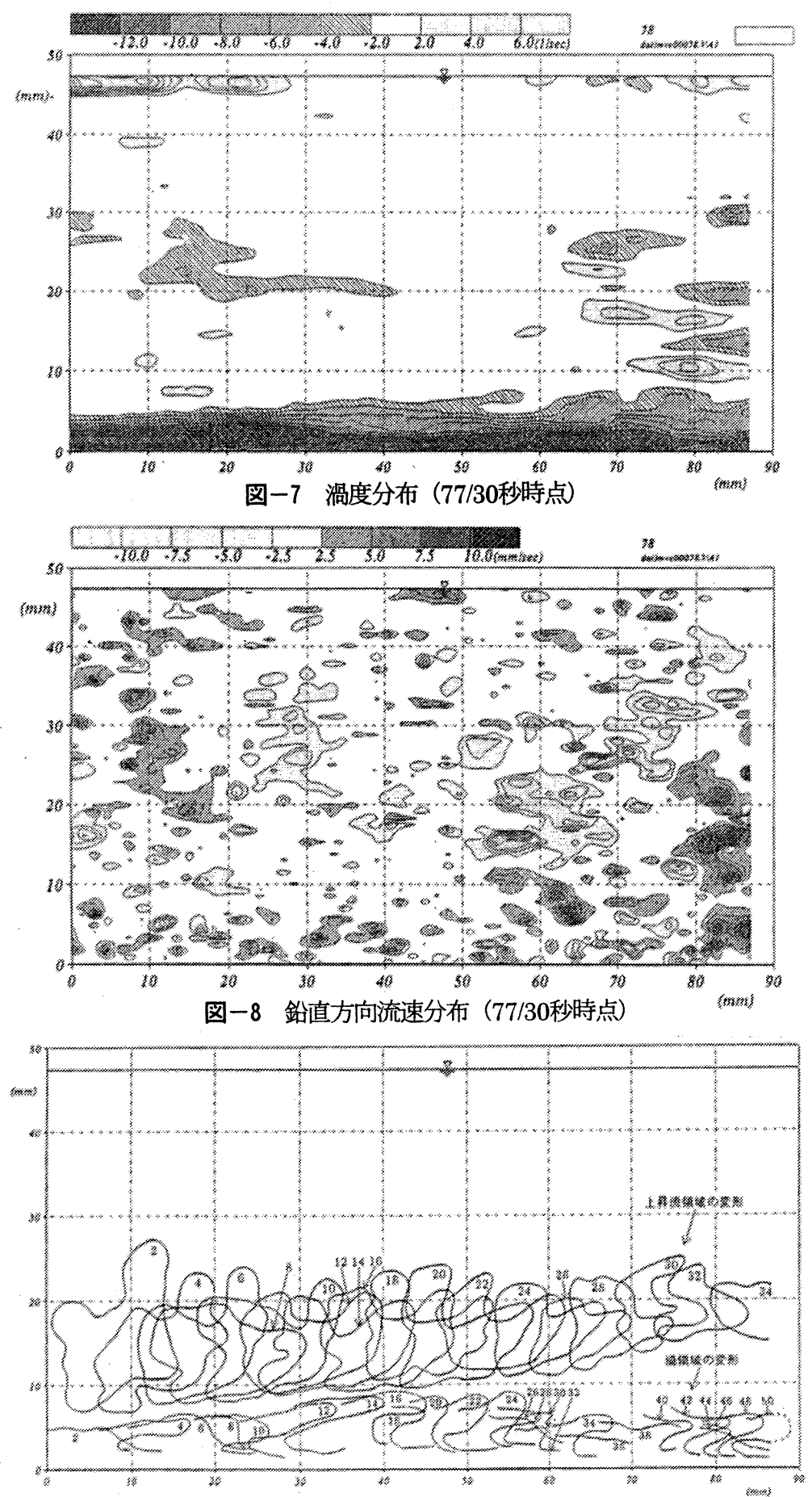

図－9 渦と上昇流領域の移動と变形（数字はフレーム番号を示す） 

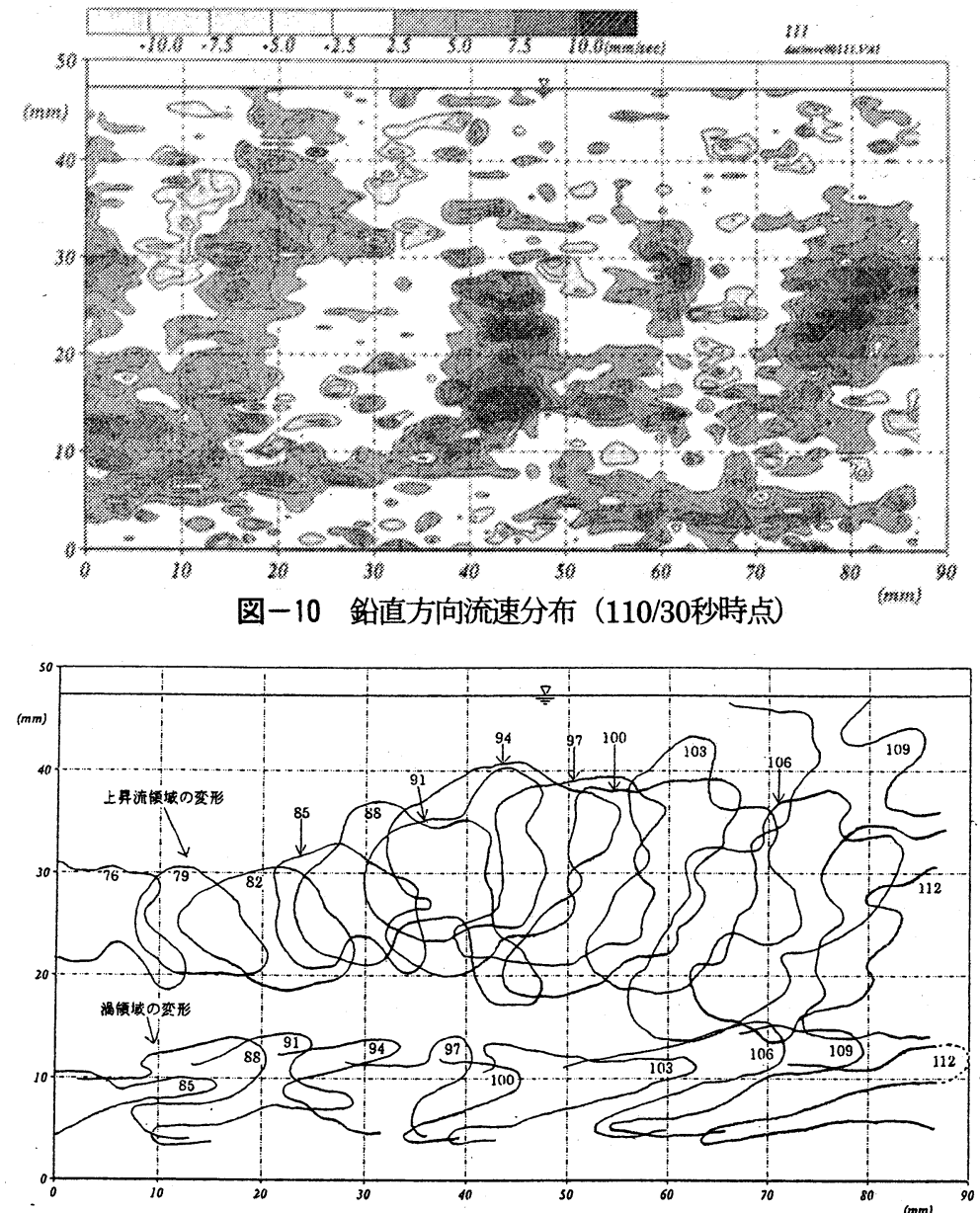

図一11 渦と上昇流領域の移動と変形（数字はフレーム番号を示す）
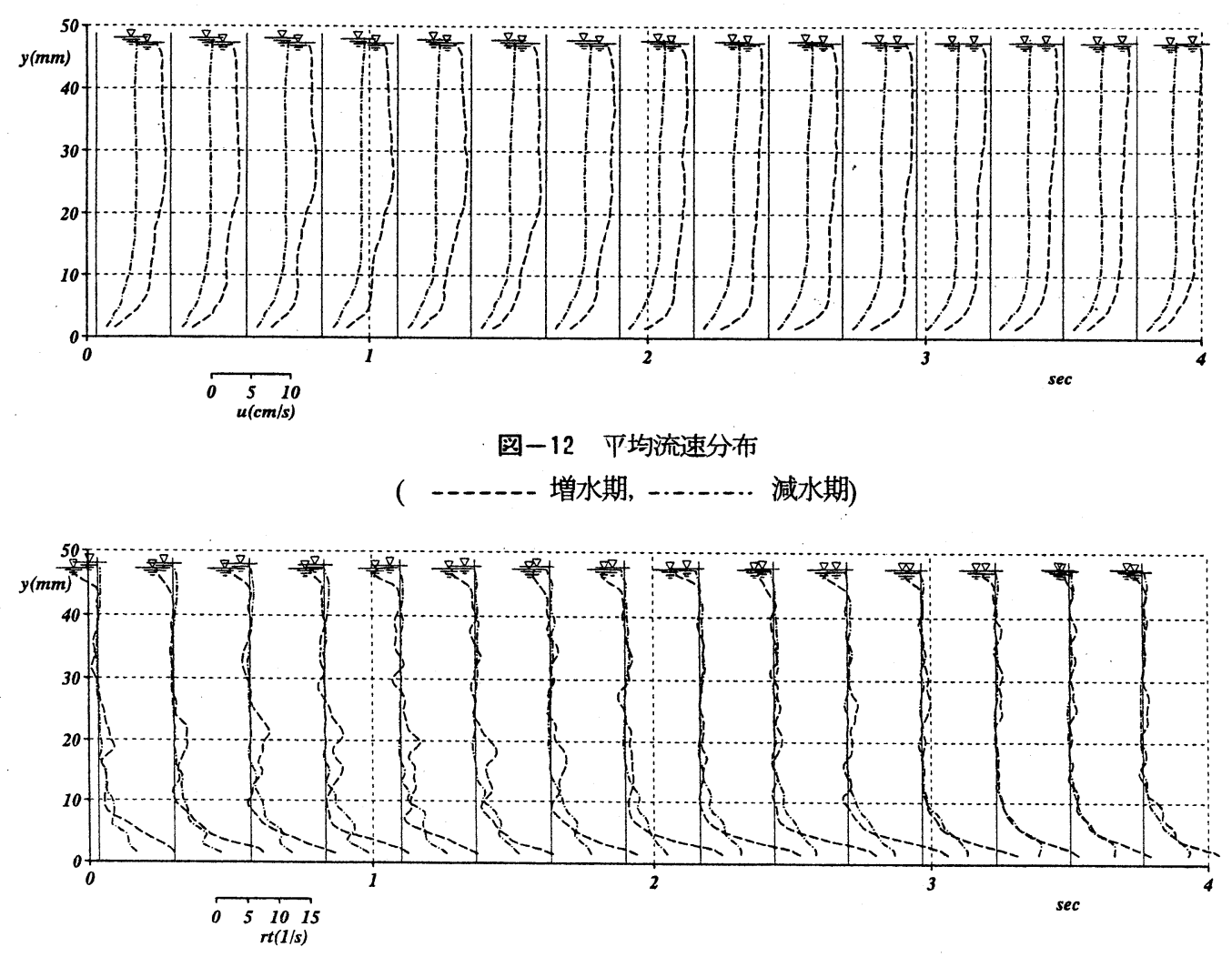

図一13 水平方向に平均された渦度分布の鉙直方向分布

( - - . . . 增水期, …...... 減水期) 


\section{（2）増水期と減水期の比較}

減水期のうち解析区間4秒間の前半は増水期で見られ たのと同様の渦度分布が見られ、水路床近傍で逆U字渦 が確認できる。増水期で述べた逆U字渦がもたらす上方 への流れの噴出や、水路床近傍から水面まで達する上 昇流領域の形成は減水期においても同様に発生してい る。

しかし、これらはいずれも増水期ほど顕著ではなく、 4秒間の後半部については、底面近傍の強い渦度の領域 も比較的薄くなり、逆U字渦の活発な動きが見られず、 乱れの少ない穏やかな流れになっている。

図ー12は8/30秒毎に平均流速分布をプロットしたもの で、増水期の分布は破線で、減水期の分布は一点鎖線 で示されている。本図から、水路床近傍における増水 期の速度勾配は減水期のそれに比べて大きくなってい ることがわかる。長谷川122 はこの現象が加速度の影響 であることを流れの運動方程式に基づいて説明した。

図一13は、8/30秒毎に、水平方向に平均された渦度の 鉛直方向分布をプロットしたもので、増水期の分布は 破線で、減水期の分布は一点鎖線で示されている。本 図から、増水期における水路床近傍での渦度は、減水 期の約 2 倍程度になっていること、また、とくに解析区 間4秒間の前半において、増水期は水路床付近を離扎る と急激に渦度の值が減少し、水深半ば程で再び増加す るのに対し、減水期では水路床付近を離れても急には 減少せず、徐々に減少してゆき、水深半ば程で0に近づ くことがわかる。すなわち、水路床近くにおける増水 期と減水期の渦度分布の違いは平均流速分布の違いを 反映している。ちなみに、増水期における全断面の平

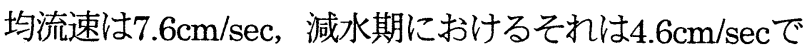
ある。

\section{5. おわりに}

実験水路における非定常流の縦断面内の流況をビデ 才画像解析の手法を用いて経時的に解析した結果、以 下のような結論が得られた。

(1) 強い上昇流領域が逆U字渦により水路床近くに形成 される。

(2)この上昇流領域は時間経過と共に、変形しながら 平均流によって運搬され、流下方向に移動する。 また、流れてきた上昇流領域が水路床近傍の逆U字
渦による噴出流により加速されたとき、大規模な 上昇流領域が形成されるようである。

(3) この領域が水面に達した時、ボイルが発生すると 考えられる。

(4) 流下方向に断続的に連なった上昇流領域は並列ら せん流の形成に寄与していると考えられる。

\section{参考文献}

1）林泰造・大島正憲：Kinematic Waveとしての非定常性が 水流の乱れ構造に及ぼす影響の研究, 第32回水理講演会 論文集，pp. 607-612，1988

2）冨永晃宏・湯下孝司・小葉竹重機：第44回土木学会全国 大会概要集，pp. 484-485，1989

3) Haizhou, Tu. and Graf, W. : Friction in unsteady openchannel flow over gravel beds, Journal of Hydraulic Research, Vol.31, pp.99-110, 1983

4) Song, T and W. H. Graf. : Velocity and Turbulence distribution in unsteady open-channel flow, Journal of Hydraulic Engineering, pp.141-154, 1996

5）螎津家久・門田章宏・中川博次：非定常開水路流れの乱 流構造に関する実験的研究, 土木学会論文集, No. 491/ II-27, pp. 81-88, 1994

6) 螎律家久・閒田章宏・中川博次：開水路乱流の粘性低層 および壁面領域に及ぼす非定常効果，水工学論文集， Vol. 39, pp. 833-838

7) 福津家久・門田章宏・新橋秀樹・倉田昌明 : 河床波上非 定常開水路流れの時空間相関構造に関する研究，土木学 会論文集，No. 579/II-41，pp. 125-136，1997

8）襧津家久・鬼束幸樹・倉田昌明：非定常滑面開水路流内 層の特性，水工学論文集，Vol. 42，pp. 865-870，1998

9) 木下良作：航空写真による洪水流の解析, 写真測量, Vol. 6, No. 1, pp. 1-17, 1967

10) Brown, G. I. and Thomas, A. S. W. : Iarge structure in $a$ turbulent boundary layer, Phys. Fluid, Vol.20, 1977

11) Utami, T. and Ueno, T. : Experimental study on the coherent structure of turbulent open-channel flow using visualization and picture processing, J. Fluid Mech., Vol.174, pp.399-440, 1987

12）長谷川和義・市埜順也・山下章司・崇田徳彦：洪水時流 速分布の計測と結果の解析, 水工学論文集, Vol. 41, pp. 977-984, 1997

(2000.10.2受付) 